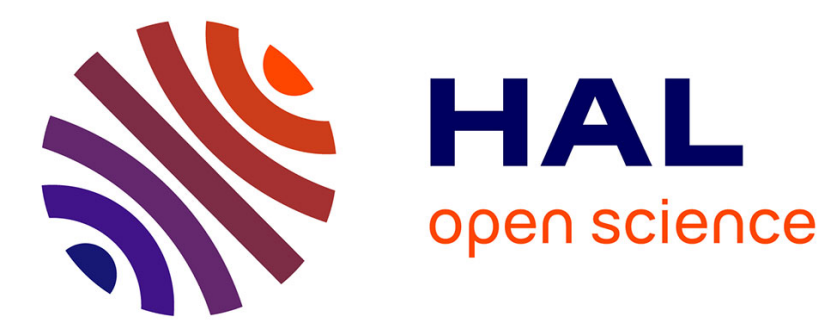

\title{
Ah receptor agonist activity in frequently consumed food items
}

Wilhelm Johan de Waard, Jac M.M.J.G. Aarts, Ad A.C.M. Peijnenburg, Theo M.C.M. de Kok, Frederik-Jan van Schooten, Ron Laurentius Hoogenboom

\section{- To cite this version:}

Wilhelm Johan de Waard, Jac M.M.J.G. Aarts, Ad A.C.M. Peijnenburg, Theo M.C.M. de Kok, Frederik-Jan van Schooten, et al.. Ah receptor agonist activity in frequently consumed food items. Food Additives and Contaminants, 2008, 25 (06), pp.779-787. 10.1080/02652030701798880 . hal00577440

\author{
HAL Id: hal-00577440 \\ https://hal.science/hal-00577440
}

Submitted on 17 Mar 2011

HAL is a multi-disciplinary open access archive for the deposit and dissemination of scientific research documents, whether they are published or not. The documents may come from teaching and research institutions in France or abroad, or from public or private research centers.
L'archive ouverte pluridisciplinaire HAL, est destinée au dépôt et à la diffusion de documents scientifiques de niveau recherche, publiés ou non, émanant des établissements d'enseignement et de recherche français ou étrangers, des laboratoires publics ou privés. 


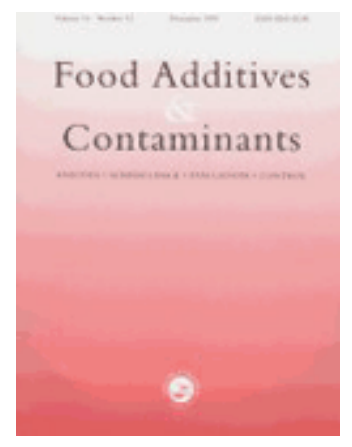

\section{Ah receptor agonist activity in frequently consumed food items}

\begin{tabular}{|c|c|}
\hline Journal: & Food Additives and Contaminants \\
\hline Manuscript ID: & TFAC-2007-328.R1 \\
\hline Manuscript Type: & Original Research Paper \\
\hline $\begin{array}{r}\text { Date Submitted by the } \\
\text { Author: }\end{array}$ & 08-Nov-2007 \\
\hline Complete List of Authors: & $\begin{array}{l}\text { de Waard, Wilhelm; RIVM, Safety Medicines and Teratology } \\
\text { Aarts, Jac; Wageningen University, Toxicology } \\
\text { Peijnenburg, Ad; RIKILT-Institute of Food Safety } \\
\text { de Kok, Theo; Maastricht University } \\
\text { van Schooten, Frederik-Jan; Maastricht University } \\
\text { Hoogenboom, Ron; RIKILT-Institute of Food Safety, Safety and } \\
\text { Health }\end{array}$ \\
\hline Methods/Techniques: & Screening - Calux \\
\hline Additives/Contaminants: & Dioxins - TEQs \\
\hline Food Types: & Many food types \\
\hline
\end{tabular}

\section{SCHOLARONE $^{\text {MT }}$ Manuscripts}



4

Table I. Estimated range of exposure of the Dutch population to NAhRAs from a number of frequently consumed food items, expressed as DR CALUX ${ }^{\circledR}$ pg TCDD-IEQ/day. The food

items are prepared according to Dutch habits, and acidified to mimic the gastric environment.

Levels based on the $24 \mathrm{~h}$ incubations of the DR CALUX ${ }^{\circledR}$ bioassay.

\begin{tabular}{|c|c|c|c|c|c|c|c|}
\hline \multirow[t]{2}{*}{$\begin{array}{l}\text { VCP-2003 } \\
\text { Product group }\end{array}$} & \multirow[t]{2}{*}{ Samples } & \multirow{2}{*}{$\begin{array}{c}\text { VCP-2003 } \\
\text { Consumption } \\
\text { g/day } \\
\end{array}$} & \multicolumn{2}{|c|}{$\begin{array}{c}\text { Range } \\
\text { pg TCDD-IEQ/g }\end{array}$} & \multicolumn{2}{|c|}{$\begin{array}{c}\text { Daily pg TCDD- } \\
\text { IEQ/day }\end{array}$} & \\
\hline & & & Lower & Upper & Lower & Upper & \\
\hline Potatoes & Mean of potatoes $\mathbf{A}^{*}$ & $\ldots-{ }_{-}-{ }_{-}$ & 1.4 & 2.4 & 130 & 226 & Formatted: Superscript \\
\hline Leaf vegetables & Lettuce & 15 & 0.0 & 0.1 & $\mathbf{0}$ & 2 & \\
\hline Fruit vegetables & Bell pepper ${ }^{*}$ & 28 & 0.2 & 0.9 & 6 & 25 & \\
\hline Tuberous vegetables & Carrot $^{*}$ & 7 & 0.0 & 0.0 & $\mathbf{0}$ & $\mathbf{0}$ & \\
\hline Crucifers & Mean of crucifers ${ }^{*}$ & 23 & 1.8 & 4.5 & 40 & 103 & \\
\hline Peas, beans & $\mathrm{Pea}^{*}$ & 3 & 0.0 & 0.0 & $\mathbf{0}$ & $\mathbf{0}$ & \\
\hline Flour & Wheat flour & 1 & 0.8 & 0.8 & 1 & 1 & \\
\hline Paste, rice & Mean of paste, rice $^{*}$ & 46 & 0.7 & 0.7 & 31 & 32 & \\
\hline Bread & Bread & 151 & 0.4 & 14.5 & 60 & 2190 & \\
\hline Fresh meat & Mean of fresh meat & 44 & 0.8 & 1.1 & 36 & 47 & \\
\hline Meat products & Hamburger ${ }_{\perp}^{\#} \ldots$ & 60 & 10.5 & 24.9 & 630 & 1494 & Formatted: Superscript \\
\hline Fish & Plaice (flatfish) $)^{ \pm}$ & 4 & 4.2 & 6.1 & 17 & 24 & \\
\hline Fruit juices & Mean of fruit juices & 159 & 3.7 & 13.1 & 594 & 2088 & \\
\hline & & & & l, pg/day & 1545 & 6232 & \\
\hline Samples hoiled & & & & & & & Formatted: Font: $10 \mathrm{pt}$, Superscript \\
\hline & & & & & & & Formatted: Font: $10 \mathrm{pt}$ \\
\hline Samples fried & & & & & & & Formatted: Font: $10 \mathrm{pt}$, Superscript \\
\hline & & & & & & & Formatted: Font: $10 \mathrm{pt}$ \\
\hline
\end{tabular}


Figure 1. Luciferase induction in rat H4IIEpGudluc1.1 cells determined by the DR CALUX $^{\circledR}$ assay, expressed as $\%$ of the maximum induction by TCDD after 4, 8, 16 and $24 \mathrm{~h}$ of exposure to 3 times diluted extracts of a number of frequently consumed food items. Bars: mean of triplicate exposures $\pm \mathrm{sd}$.

Figure 2. DR CALUX ${ }^{\circledR}$ response in a dilution range of fried (black) and fried plus acidified (grey) French fries extracts. The exposure time was 24h. Bars: mean of triplicate exposures $\pm \mathrm{sd}, * \mathrm{P}<0.05, * * \mathrm{P}<0.01$

Figure 3. DR CALUX ${ }^{\circledR}$ response in extracts of raw (black), raw plus acidified (grey), boiled (white) and boiled plus acidified (striped) potatoes, bell pepper and cruciferous vegetables. The exposure time was 24h. Bars: mean of four (potatoes, undiluted), three (bell pepper, undiluted, three different color types), or eleven (cruciferous vegetables, three times diluted, four different types) samples of vegetables $\pm \mathrm{sd}, * \mathrm{P}<0.05$

Figure 4. DR CALUX ${ }^{\circledR}$ response in three times diluted extracts of boiled (black) and boiled plus acidified (grey) pastas, rice, corn and bread. The exposure time was $24 \mathrm{~h}$. Bars: mean of triplicate exposures $\pm \mathrm{sd}, * \mathrm{P}<0.05$

Figure 5. DR CALUX ${ }^{\circledR}$ response of undiluted extracts of raw (black), fried (grey) and fried plus acidified (striped) samples from minced beaf, steak, pork, chicken breast, hamburger and flatfish (plaice). The exposure time was 24h. Bars: mean of triplicate exposures $\pm \mathrm{sd}, * \mathrm{P}<0.05, * * \mathrm{P}<0.01$ 
7

8

9

10

Figure 6. DR CALUX ${ }^{\circledR}$ response in a dilution range of orange juice (black), acidified orange juice (grey), grapefruit juice (white) and acidified grapefruit juice (striped) extracts. The exposure time was 24h. Bars: mean of seven (orange juice) of three (grapefruit juice) different types \pm sd. At the 81 times dilution only grapefruit juice has been measured. 


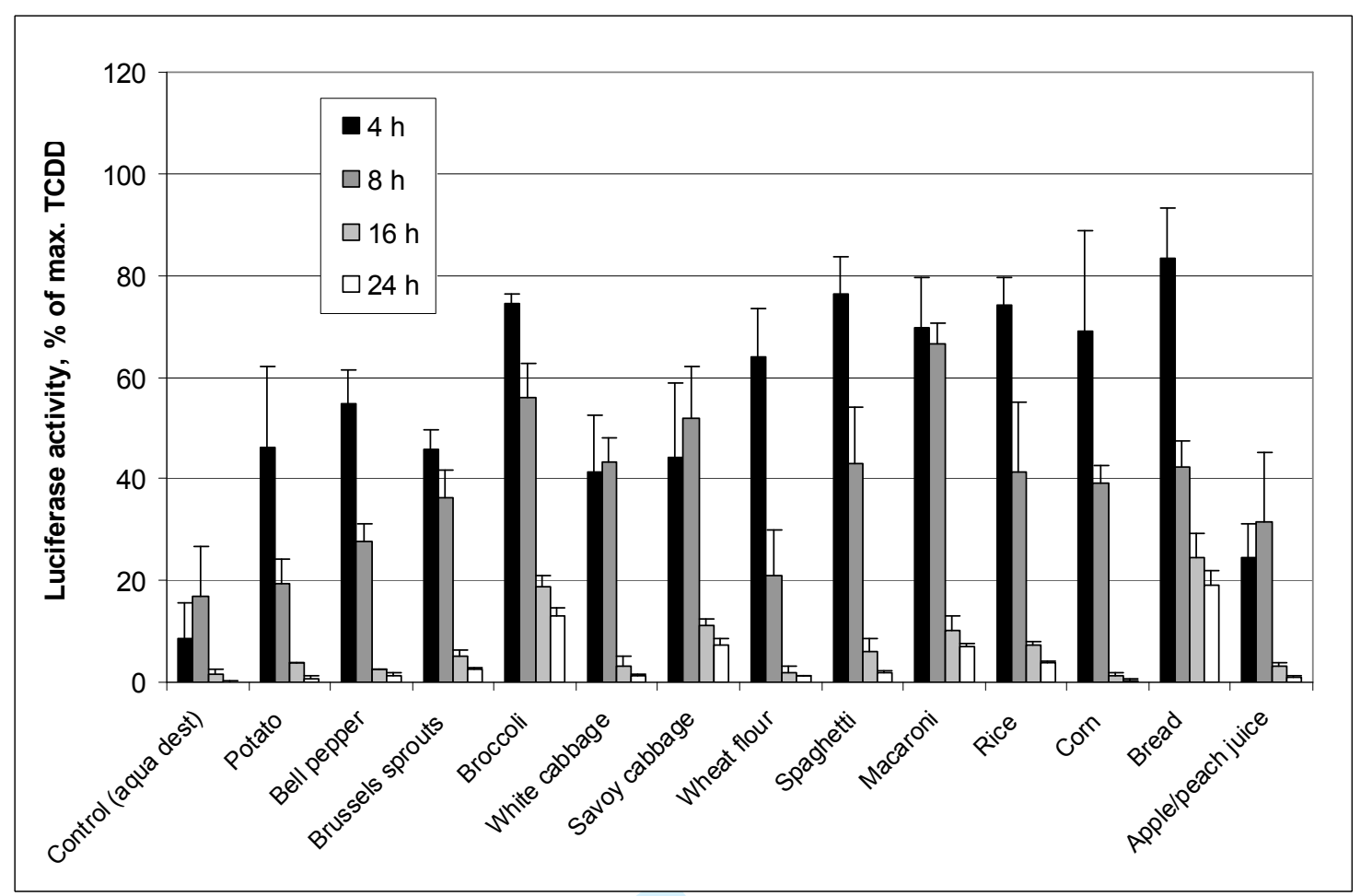

Figure 1.

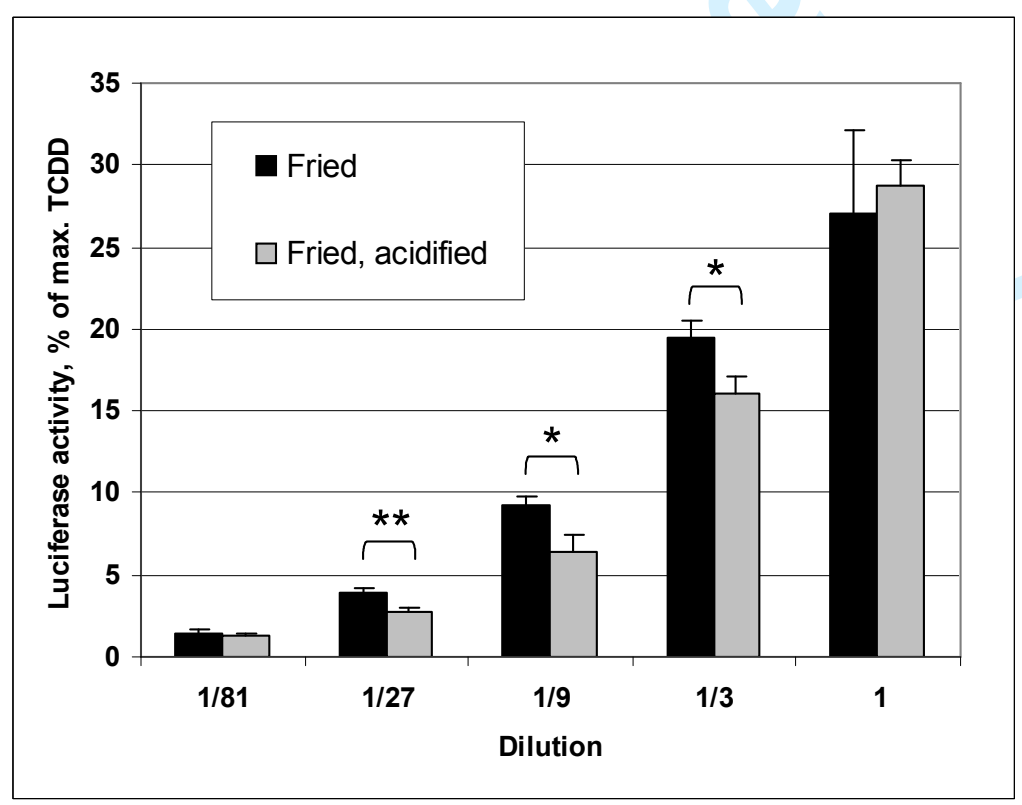

Figure 2. 


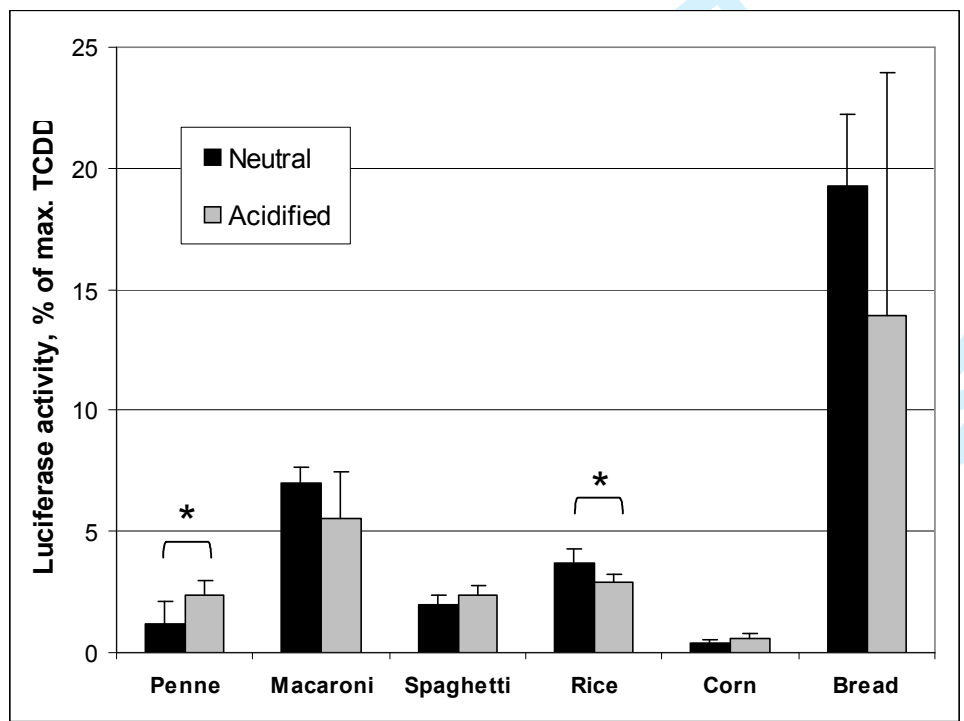

Figure 4. 


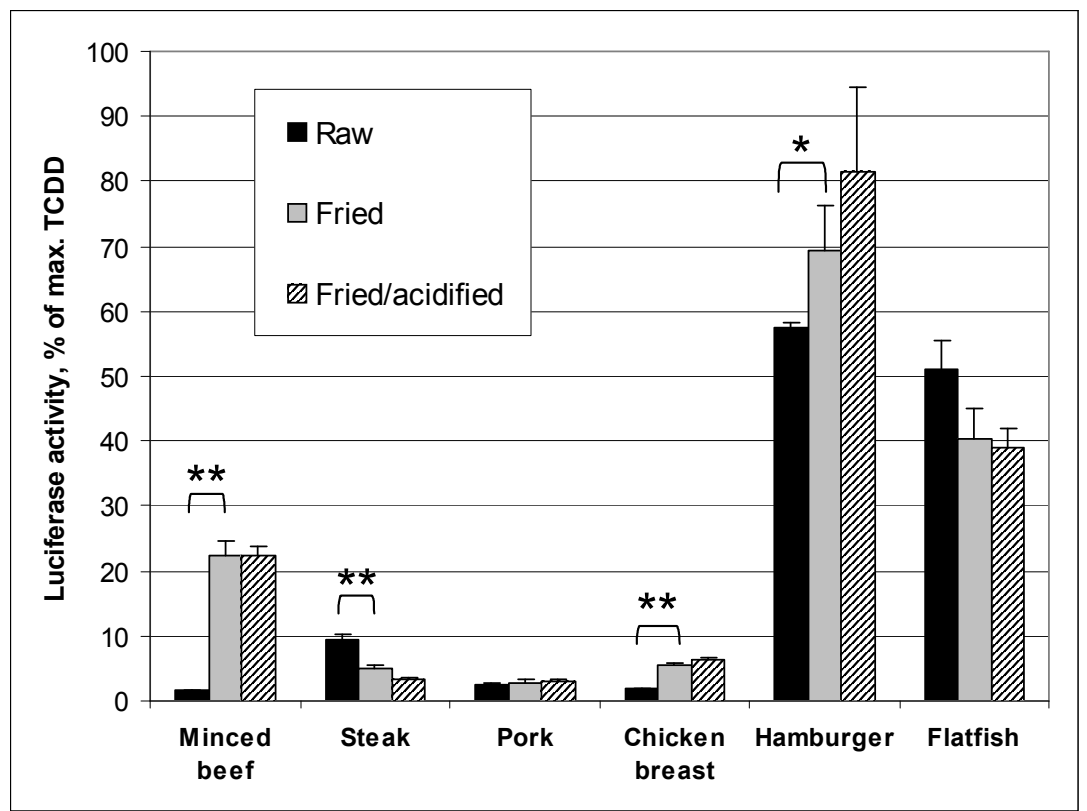

Figure 5.

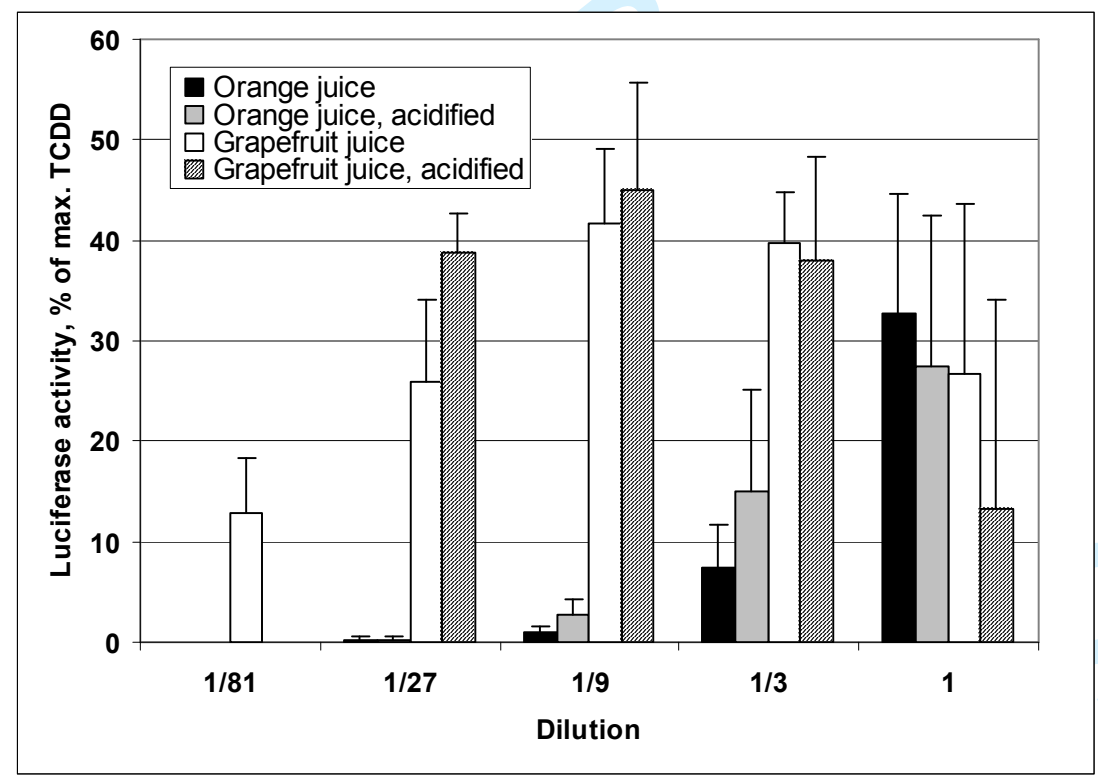

Figure 6. 
Ah receptor agonist activity in frequently consumed food items 


\begin{abstract}
The aryl hydrocarbon receptor (AhR) receives much attention for its role in the toxicity of dioxins and dioxin-like PCBs. However, also many other compounds have been reported to bind and activate the AhR, of which natural food components are of special interest from a human health perspective. Using the DR CALUX ${ }^{\circledR}$ bioassay, we screened extracts from many food items, frequently consumed in The Netherlands, to estimate the intake of natural AhR-agonists (NAhRAs). Using the prototypical AhR-agonist TCDD as standard, we estimated that the daily intake of NAhRAs may be considerably higher than the reported intake of dioxins and dioxinlike PCBs. Potatoes, cruciferous vegetables, bread, hamburgers and grapefruit juice contained most NAhRAs. Food preparation and acid treatment can show a significant effect on the AhRactivation. Interaction of natural and xenobiotic AhR-agonists should be taken into account when performing risk-benefit analysis of both types of compounds.
\end{abstract}

Key words: Ah receptor, TCDD, food, fytochemicals, DR CALUX ${ }^{\circledR}$ 


\section{Introduction}

The aryl hydrocarbon receptor (AhR) is a cytosolic ligand-activated transcription factor, which is present in many cell types of mammals, including humans. At the moment, there is still no consensus about the biological function of this receptor. However, it received much attention for its role in the toxicity of dioxins, especially the most potent activator 2,3,7,8-tetrachlorodibenzo-p-dioxin (TCDD) (Hankinson 1995; Safe 2001).

Not only contaminants like dioxins, PCBs and PAHs can bind to the AhR, but also a large number of compounds of natural origin can bind to and activate this receptor. Surprisingly, these compounds can have very different chemical structures, which indicates that this receptor has a rather promiscuous ligand binding site (Denison and Nagy 2003; Safe 1998). One of the most investigated natural AhR agonists (NAhRAs) is indole-3-carbinol (I3C), which is formed in cruciferous vegetables (Brussels sprouts, broccoli, cabbage) by an enzymatic reaction after crushing of the plant tissues. During consumption, I3C undergoes self-condensation into a number of oligomers and indolo[3,2-b]carbazole (ICZ) in the acid environment of the stomach. Although ICZ is formed in very low amounts (ca $0.0002 \%$ ), its AhR activating potency is relatively high (Bjeldanes and others 1991). Also many other food items have been shown to contain relatively large amounts of NAhRAs, of which the chemical identity of the receptoractivating compounds is often unknown (Jeuken and others 2003).

In contrast with the prototypical AhR agonist TCDD and related toxic compounds, the NAhRAs do apparently not show clear toxic effects at normal dietary exposure levels; on the contrary, they even seem to have beneficial health effects. Many researchers attribute this to the induction of a number of phase I and II detoxifying biotransformation enzymes, like the cytochrome P450s CYP1A1, CYP1A2, GSTP, and 
NQO1 (Kim and Milner 2005; Rogan 2006). However, these enzymes are induced by the activation of the AhR, and are thus also induced by TCDD and other toxic dioxinlike contaminants. A distinctive property of the NAhRAs seems to be their rapid clearance from the body, resulting in an essentially transient effect on the expression of AhR-regulated genes as compared to the more persistent xenobiotic AhR agonists (Chen and others 1995; Pohjanvirta and others 2002). Another property that seems to distinguish many NAhRAs from e.g. dioxins is their ability to inhibit the enzymatic function of P450 enzymes, and even to inhibit AhR activation by TCDD (Amakura and others 2002; Pohl and others 2006). This raises the question whether humans are exposed to such an amount of NAhRAs that they could inhibit the possible toxic effects of compounds like dioxins and PAHs or that they may present a risk hazard because of their AhR agonist activity.

The purpose of our study was to examine the AhR-activating properties of a number of food items frequently consumed in The Netherlands, in order to identify sources of NAhRAs and relate their intake by humans to that of dioxin-like AhR-activating food contaminants. We prepared the food samples in the way they are consumed normally by Dutch consumers, and we included treatment of the samples with hydrochloric acid ( $\mathrm{HCl})$ to mimic the acid environment of the stomach. A low $\mathrm{pH}$ could theoretically hydrolyse unstable NAhRAs and deactivate them, but on the other hand, some natural compounds, like I3C, can be transformed by acidification into relatively strong $\mathrm{AhR}$ agonists such as ICZ. Comparing the AhR-activation by the NAhRAs, as measured with the DR CALUX ${ }^{\circledR}$ assay, with the activity of TCDD, and relating this to the Dutch Food Consumption Survey of 2003 (Hulshof and others 2004), provided us with an estimation of the theoretical load of NAhRAs in the human diet. Because of the difficulty to 


\section{Preparation of food extracts}

All food items were bought at local supermarkets. Solid foods were grinded by a food chopper T71 (Moulinex, Woerden, The Netherlands). Five gram of fresh solid food or $10 \mathrm{ml}$ of liquid food was mixed with $20 \mathrm{ml}$ of methanol/water $85 / 15$, and after $30 \mathrm{~min}$ of soaking, extracted twice with $20 \mathrm{ml}$ of n-hexane/diethyl ether 97/3 by mixing for $1 \mathrm{~h}$ in an overhead mixer (REAX 2, Heidolph, Germany), followed by centrifugation at $3000 \mathrm{rpm}$ for $10 \mathrm{~min}$. Hexane-layers were collected, evaporated in a Speedvac (Hetavac VR-1, Birkerod, Denmark) and the residue dissolved in $40 \mu \mathrm{l}$ of DMSO (Merck, Darmstadt, Germany). In order to mimic the acid environment of the stomach, in addition grinded samples were $1: 1$ mixed with $0.1 \mathrm{M} \mathrm{HCl}$, adjusted to $\mathrm{pH}=1$ with $1 \mathrm{M}$ $\mathrm{HCl}$ (Merck, Darmstadt, Germany), and mixed for an hour before addition of the methanol/water. When relevant, samples were boiled before grinding according to common Dutch kitchen practises, and afterwards, also the boiling water was collected for examination. Extracts from food samples containing fat, like bread and meat, were 
defatted in order to prevent incomplete mixing with the medium. Extract residues containing $40 \mu \mathrm{l}$ DMSO were dissolved in $15 \mathrm{ml}$ of eluent (cyclohexane/ethylacetate 1/1 $\mathrm{v} / \mathrm{v}$ ), of which $12.5 \mathrm{ml}$ were inserted into a gel permeation chromatography system (Gilson). Fat was separated by a BioBeads SX3 column (i.d. $2.5 \mathrm{~cm}$, length $60 \mathrm{~cm}, 200-$ 400 mesh), and the eluted fraction from 44 to 107 min was collected and evaporated until $40 \mu \mathrm{l}$ DMSO. To check for contamination with dioxin-like persistent AhR agonists, hexane-extracts of a number of samples were transferred on a column containing $10 \mathrm{~g}$ acid silica $\left(33 \% \mathrm{H}_{2} \mathrm{SO}_{4}\right)$, on which NAhRAs are removed (Hoogenboom and others 2006b) and subsequently tested for residual AhR-agonist activity by DR CALUX ${ }^{\circledR}$ analysis.

\section{Cell culture and treatment}

DR CALUX $^{\circledR}$ cells (rat H4IIE hepatoma cells stably transfected with pGudluc1.1, an AhR-regulated luciferase reporter plasmid) (Aarts and others 1995) were grown in $\alpha$ MEM (Sigma, St-Louis, USA), containing 10\% fetal bovine serum (GIBCO, Breda, The Netherlands) and $1 \%$ penicillin/streptomycin (Sigma), at $37^{\circ} \mathrm{C}$ and $5 \% \mathrm{CO}_{2}$. Cells were seeded $24 \mathrm{~h}$ before exposure in Costar 48 well-plates $\left(5.10^{4}\right.$ cells/well $)$ and exposed for $24 \mathrm{~h}$ to sample solutions in DMSO added to the culture medium. During each experiment, a calibration curve was made of 0.5-500 pM TCDD (Schmidt BV, Amsterdam, The Netherlands). The undiluted sample concentration of the solid foods was equivalent to $1250 \mathrm{mg}$ fresh product per $\mathrm{ml}$ exposure medium, except for the meat samples and fish, of which the concentration was $625 \mathrm{mg} / \mathrm{ml}$. The undiluted concentration of the liquid samples was $2500 \mathrm{mg} / \mathrm{ml}$. Samples were also diluted 3, 9, 27 
or 81 times. The final concentration of DMSO in all exposures was $1.0 \%(\mathrm{~V} / \mathrm{V})$. In addition, a number of samples were also exposed for 4,8 and $16 \mathrm{~h}$.

DR CALUX $X^{\circledR}$ assay

The Dioxin Receptor - Chemical-Activated LUciferase gene eXpression assay was performed as described previously (Bovee and others 1998). After exposure of the cells in 48-well microtiter plates the medium was removed and cells were washed with PBS. Cells were lysed using Cell Culture Lysis Reagent (Promega), centrifuged and $20 \mu \mathrm{l}$ of lysed solution of each well was transferred to a 96 wells plate. Luminescence was measured with a LuminoskanAscent (Thermo Labsystems, Finland) upon addition of $0.1 \mathrm{ml}$ of luciferin assay mixture $\left(20 \mathrm{mM}\right.$ Tricine, $1.07 \mathrm{mM}\left(\mathrm{MgCO}_{3}\right)_{4} \mathrm{Mg}(\mathrm{OH})_{2} \cdot 5 \mathrm{H}_{2} \mathrm{O}$, $2.67 \mathrm{mM} \mathrm{MgSO}{ }_{4} \cdot 7 \mathrm{H}_{2} \mathrm{O}, 0.1 \mathrm{mM}$ EDTA, $33.3 \mathrm{mM}$ DTT, $261 \mu \mathrm{M}$ Coenzyme A, 470 $\mu \mathrm{M}$ Luciferin, $530 \mu \mathrm{M}$ ATP, $\mathrm{pH}$ 7.8). Using the program SlideWrite V6, the curve $\mathrm{y}=\mathrm{a} 0 /\left(1+(\mathrm{x} / \mathrm{a} 1)^{\wedge} \mathrm{a} 2\right)$, which describes the AhR activation process suitably (Hoogenboom and others 2006a) was fitted for the data and the response maximum of TCDD and the TCDD luciferase induction equivalents (TCDD-IEQs) of the food extracts were calculated.

\section{Statistics}

Statistical analyses were performed by use of the 2-side Student's t-test. Effects of acidification or boiling of groups of foods were tested paired.

\section{Results}


By use of the DR CALUX ${ }^{\circledR}$ bioassay, the Ah-receptor activity was measured in extracts from a number of food items, regularly consumed in The Netherlands. To rule out the effects of possible contamination with dioxins and other persistent AhR agonists, a number of samples with relatively high luciferase induction has been examined by use of the acid silica clean up procedure which destroys the more labile natural AhR agonists. None of the acid silica treated samples showed a significant induction of the luciferase reporter gene expression, except for the flatfish, which showed a CALUX activity of about one-third of the non acid silica treated sample (results not shown). To establish whether the food extracts showed a similarly persistent response as TCDD, the CALUX cells were also exposed for 4,8 and $16 \mathrm{~h}$ to a number of samples. Most of the samples induced luciferase 20-70 times more during $4 \mathrm{~h}$ and $8 \mathrm{~h}$, than during $24 \mathrm{~h}$ of exposure, both at the 3 (Figure 1) and 27 times dilutions (results not shown). The $16 \mathrm{~h}$ exposures showed less difference with $24 \mathrm{~h}$ (1-3 times). Apparently, the AhR agonists in all samples are less persistent in activity than TCDD, probably because of their faster metabolism or faster increase in response compared with TCDD.

\section{DR CALUX ${ }^{\circledR}$ response in food items}

Figure 2 to 6 show the AhR activity in extracts of a number of food items frequently consumed in the Netherlands, as measured by the DR CALUX ${ }^{\circledR}$ assay after $24 \mathrm{~h}$ of exposure. All samples were tested in dilution ranges, but for clarity reasons not all dilutions are shown. The influence of acidification has been determined for most of the food samples, and where relevant according to the habitual Dutch food preparation, also the effect of boiling has been studied. The results are reviewed in the same order of product groups as described in the Dutch Food Consumption Survey of 2003 (Hulshof 
and others 2004). The limit of detection of the used DR CALUX ${ }^{\circledR}$ assay is $0.5 \mathrm{pM}$ TCDD (Hoogenboom and others 2006a), which corresponds with a luciferase induction of about $1 \%$ of the maximum induction caused by TCDD. In this study, a luciferase induction of $2 \%$ is assumed to be a significant activation of the AhR, corresponding to a limit of quantitation (LOQ) of $0.1 \mathrm{pg}$ TCDD-luciferase induction equivalents (TCDDIEQ) per gram of undiluted sample. After boiling the vegetables, the boiling water was collected and also examined for AhR activation, but the luciferase induction by these water extracts was negligible.

Potatoes. French fries contained a considerable amount of inducing compounds (up to $28 \%$ induction, Figure 2). At three dilutions, the acidification reduced the luciferase activity significantly by $20-30 \%$. Potatoes showed a significant luciferase activity of about $4-7 \%$ of the TCDD maximum at the highest concentration. Boiled potatoes showed significant less induction than acidified raw potatoes (Figure 3).

Lettuce, carrot and pea. The DR CALUX ${ }^{\circledR}$ response of these vegetables was near or below $1 \%$ of TCDD maximum at the highest concentration (results not shown).

Bell pepper. Three different color types of bell pepper were examined. Undiluted samples showed an activity of 4-6\% of TCDD maximum. Acidification of the boiled vegetables increased the activity significantly (Figure 3 ).

Cruciferous vegetables. Four types of cruciferous vegetables have been examined: Brussels sprouts, broccoli, Savoy cabbage and white cabbage. All of them showed a relatively strong luciferase induction. Although Brussels sprouts tended to be the most strongly activating vegetable, the differences were not significant and the mean of all types has been plotted in Figure 3. As expected in view of the known acid induced NAhRAs like I3C in cruciferous vegetables, acidification increased the response 
significantly by 2.8 (acified vs raw) to 2 (boiled and acidified vs raw) times. Boiling did not have a large effect on luciferase induction.

Paste, rice and corn. Penne, macaroni, spaghetti and rice but not corn could induce the DR CALUX ${ }^{\circledR}$ response by $2-7 \%$. Acidification increased the response of penne, and decreased the response of rice significantly (Figure 4).

Bread. Bread showed a significant response of $15-20 \%$ at the highest concentration (Figure 4). Acidification decreased the response, but not significantly. Wheat flour was very low in AhR activity (results not shown).

Meat and fish. Very high levels of AhR activity, up to $80 \%$ of the TCDD maximum, were observed with hamburgers and the flatfish plaice, and to a lesser extent with fried minced beef (Figure 5). Raw minced beef showed no significant response and frying also increased the response of chicken breast and hamburger, but decreased the response of steak significantly. Acidification of the fried samples had no significant influence on the luciferase induction.

Fruit juices. Undiluted orange juice showed a moderate activity of up to $30 \%$ of the TCDD maximum, while grapefruit juice highly induced the luciferase activity up to ca. $40 \%$ at low concentrations (Figure 6). Undiluted samples of grapefruit juice extracts were clearly cytotoxic, and also the 3-times dilutions were less active. Acidification of these fruit juices had no significant effect on the AhR induction, probably also because of the low $\mathrm{pH}$ of the juices themselves $(\mathrm{pH}=3.2)$.

\section{Human exposure with NAhRAs}

To estimate the amount of AhR-activating substances found in the human diet, we calculated their contribution to the DR CALUX ${ }^{\circledR}$ induction relative to the induction by 
TCDD, and expressed it as pg TCDD luciferase induction-equivalents (TCDD-IEQ, Table I). In this way TCDD has been used as a normalization standard for AhR-activity as measured by DR CALUX ${ }^{\circledR}$, enabling comparison with AhR-agonist levels in food items reported in literature. We emphasize that this does not imply a comparison to TCDD-toxicity. It was decided to use only the $24 \mathrm{~h}$ exposure data. Because the slope of the dose-response curves varies considerably between food extracts and TCDD, lower and upper limits of the DR CALUX ${ }^{\circledR}$ inductions were determined over the range of food extract dilutions tested, and the means of the representatives of the product groups are compared with the mean daily consumptions of the food items as reported in the Dutch Food Consumption Survey of 2003 (Hulshof and others 2004). Where appropriate, only acidified and boiled samples were taken into account. Table I shows that the total TCDD-IEQ amounts to $1545 \mathrm{pg} / \mathrm{day}$ at the lowest estimation, and $6235 \mathrm{pg} / \mathrm{day}$ at the highest. Of all tested food extracts, potatoes, cruciferous vegetables, bread, hamburgers and fruit juices are the most important sources of AhR agonist activity for the average consumer. The 81-times diluted grapefruit juice extract showed the highest relative DR CALUX $^{\circledR}$ activity of 41 pg TCDD-IEQ per g of product (results not shown). Because of the relatively small sampling of food items in our study, the overall exposure of the Dutch people to these kind of bioactive compounds will probably be significantly higher.

\section{Discussion}

Many compounds of natural origin appear to be AhR-agonists and extracts of many food items were found to have a significant influence on the AhR activity as measured 
by in vitro and in vivo assays (Amakura and others 2002; Amakura and others 2003; Jeuken and others 2003; Leibelt and others 2003; Nishiumi and others 2006; Pohl and others 2006). Some of these compounds and mixtures showed both activating and inhibiting effects on the AhR pathway. Very high estimates of AhR activating potential by natural food components have been reported (Jeuken and others 2003; Safe 1998). However, a systematic inventory of the exposure of humans to NAhRAs in food has not been made. By analyzing a variety of food items frequently taken by Dutch consumers, and including the effect of food preparation and acidification, we showed in this study that the intake of NAhRAs through the diet is probably not as high as previously thought (Jeuken and others 2003; Safe 1998), but still much higher than the intake of persistent xenobiotic AhR agonists (Baars and others 2004).

French fries, cruciferous vegetables, bread, hamburgers and citrus juices showed the most important AhR agonist activity of the food extracts we examined. Many natural compounds which can cause the AhR-activity in these food items may not have been identified yet. In cruciferous vegetables, the AhR agonists are attributed to the acid reaction products of indole-3-carbinol (I3C). In baked or fried foods, like fries, bread and meat products, the activity may be caused by compounds which originate from the formation of polycyclic aromatic hydrocarbons (PAHs), heterocyclic amines or Maillard products during the food preparation process at high temperatures. Also blood rests in meat may contribute to the AhR activity; heme degradation products like bilirubin and biliverdin are reported as AhR agonists. Polyphenols and furocoumarins are probably responsible for the shown activity in citrus fruit products (Denison and Nagy 2003).

Expressing the levels of NAhRAs in food in TCDD-IEQs may suggest that the responsible components represent a certain level of $\mathrm{AhR}$-mediated toxicity according to 
the TEQ (toxic or dioxin equivalent) approach as described by Safe (Safe 1998). However, we emphasize that we only used TCDD-IEQs to compare AhR activity, because the NAhRAs do probably not meet some of the important requirements for the TEQ-principle, namely additivity, and more important, persistance (Safe 1998). However, TCDD is a very potent agonist, and shows very reproducible results in the DR-CALUX $^{\circledR}$ assay, which makes it an ideal standard for the expression of relative AhR agonist activity. This implies that our results can not be interpreted as direct measurements of toxicity of food components, but only reveal the AhR activation effects, expressed as TCDD-IEQs or luciferase induction equivalents. Because the slopes of the dose-response curve of NAhRAs and PAHs differ from that of dioxins, the dilution of the samples has an important effect on the results of the calculation of $\mathrm{pg}$ TCDD-IEQs/g sample (Windal and others 2005). Because of the probably fragile nature of many natural compounds, it is important to include effects like food preparation and the effect of acidification in the gastric environment on the levels of AhR agonist activity. Frying and acidification can have a significant influence on AhR activity, boiling to a much lesser extent and the loss of AhR agonists in the boiling water was negligible.

The exposure time is another important factor in AhR activity measurement. Natural compounds, but also some PAHs like benzo[a]pyrene, can be metabolized very quickly in comparison with TCDD (Chen and others 1995; Machala and others 2001; Pohjanvirta and others 2002). In our study, the luciferase induction after $4 \mathrm{~h}$ exposure to TCDD has reached only about $30 \%$ of its maximum after $24 \mathrm{~h}$, whereas the induction by PAHs and NAhRAs is higher at $4 \mathrm{~h}$ than at $24 \mathrm{~h}$ of exposure. As a result, a relatively short exposure time of $4 \mathrm{~h}$ will show a much higher luciferase induction by NAhRAs 
and PAHs compared with TCDD, than after $24 \mathrm{~h}$ of exposure. This may explain the large difference between some results of Jeuken et al. (2003) and ours. They found e.g. $640 \mathrm{pg}$ TCDD-IEQ/g in potato, where we found 1.4-2.4 pg TCDD-IEQ/g (Table I). However, based on our measurement with the $4 \mathrm{~h}$ exposure time, we found in line with Jeuken et al. a much higher amount of $110-332 \mathrm{pg}$ TCDD-IEQ/g in potato. The interpretation of DR-CALUX ${ }^{\circledR}$ measurements on extracts of food items is thus very complicated, and we do not pretend to give a conclusive opinion about their eventual toxic potential in the human diet. Important, however, is to obtain an estimation which shows whether the exposure to NAhRAs is considerably higher than to xenobiotic AhR agonists such as dioxins and other persistent compounds in the human diet, or much lower and negligible. In 1999, the estimated intake of the sum of dioxins and dioxin-like PCBs in The Netherlands was 1.2 pg WHO-TEQ per kg body weight (bw) per day, which would be for a person weighing $70 \mathrm{~kg} 84 \mathrm{pg}$ WHO-TEQ. Of this population was $8 \%$ exposed to intake levels above the tolerable weekly intake for dioxins and dioxinlike PCBs of 14 pg WHO-TEQ per kg bw per week, or over 140 pg WHO-TEQ per person per day. The average dietary intake of these xenobiotic AhR agonists in 1978 was nearly 700 pg WHO-TEQ per person per day (Baars and others 2004). These levels are that far below the theoretical levels estimated by Jeuken et al. (e.g. $96000 \mathrm{pg}$ TCDD-IEQ per serving of 150 g potato), or our study (1545-6235 pg TCDD-IEQ/day for part of the average daily diet), that the regular intake of NAhRAs should be seriously evaluated with regard to the biological meaning of the level of AhR activation that they may cause. On the one hand, the omnipresence of the competing natural AhR agonists, together with the presence of many AhR antagonists (Amakura and others 2002; Amakura and others 2003; Baumgart and others 2005) in food, may appear as a 
prophylaxis against xenobiotic intoxication via the AhR. On the other hand, several human studies showed AhR responsive effects, like CYP1A2 induction, by several nondioxin like AhR agonists such as NAhRAs from cruciferous vegetables (Kall and others 1996; Murray and others 2001), I3C (Reed and others 2005), the anti-ulcer drug omeprazole (Rost and others 1992), and heterocyclic aromatic amines (Sinha and others 1994). This seems to be in contrast with a regular exposure to numerous AhR agonists in the human diet, which would constantly elevate the AhR activity. Another major problem in this is, that the exact pathways by which the xenobiotic dioxins and dioxinlike PCBs exert their toxicity are not well understood (Guzelian and others 2006; Steenland and others 2004). This makes it very difficult to understand to what extent NAhRAs, in amounts effective to cause AhR related effects, e.g. CYP1A2 induction by concentrated food additives, also can initiate dioxin-like toxic pathways, especially when slow processes like tumor promotion are involved. Besides tumor suppressing capacity, high doses of NAhRAs given to laboratory animals have sometimes also shown tumor promoting capacity (Dashwood 1998), and the accumulation effect of persistent fat-soluble xenobiotic AhR agonists could be mimicked by constant or regular NAhRA exposure.

In conclusion, this study confirms to a certain extent that the human diet contains a large amount of AhR-activating substances of natural origin, which triggers questions about the potential effects in humans, also in relation to the intake and adverse effects of xenobiotic dioxins and dioxin-like PCBs. In order to elucidate the potential toxicity or health-beneficial properties of these relatively large amounts of bioactive dietary components, the toxic pathway(s) of dioxins in humans should be elucidated first. This would give indications at what critical steps of the toxic pathway(s) the NAhRAs would 
have a significant dioxin-like toxic effect or on the contrary, induce totally different or even beneficial health effects, and what ultimately the predominant effect or the balance of all these effects would be.

\section{Acknowledgement}

The authors thank Kyoko Sato, Liza Portier, Karin van Ede and Cornelis van de Kraats kindly for their important contribution to the sample treatment and the DR CALUX ${ }^{\circledR}$ analysis. The Dutch Centre of Human Nutrigenomics (CHN) supported this study. 


\section{References}

Aarts JM, Denison MS, Cox MA, Schalk MA, Garrison PM, Tullis K, de Haan LH, Brouwer A. 1995. Species-specific antagonism of Ah receptor action by 2,2',5,5'-tetrachloro- and 2,2',3,3'4,4'-hexachlorobiphenyl. Eur J Pharmacol 293(4):463-74.

Amakura Y, Tsutsumi T, Nakamura M, Kitagawa H, Fujino J, Sasaki K, Yoshida T, Toyoda M. 2002. Preliminary screening of the inhibitory effect of food extracts on activation of the aryl hydrocarbon receptor induced by 2,3,7,8tetrachlorodibenzo-p-dioxin. Biol Pharm Bull 25(2):272-4.

Amakura Y, Tsutsumi T, Sasaki K, Yoshida T, Maitani T. 2003. Screening of the inhibitory effect of vegetable constituents on the aryl hydrocarbon receptormediated activity induced by 2,3,7,8-tetrachlorodibenzo-p-dioxin. Biol Pharm Bull 26(12):1754-60.

Baars AJ, Bakker MI, Baumann RA, Boon PE, Freijer JI, Hoogenboom LA, Hoogerbrugge R, van Klaveren JD, Liem AK, Traag WA and others. 2004. Dioxins, dioxin-like PCBs and non-dioxin-like PCBs in foodstuffs: occurrence and dietary intake in The Netherlands. Toxicol Lett 151(1):51-61.

Baumgart A, Schmidt M, Schmitz HJ, Schrenk D. 2005. Natural furocoumarins as inducers and inhibitors of cytochrome P450 1A1 in rat hepatocytes. Biochem Pharmacol 69(4):657-67.

Bjeldanes LF, Kim JY, Grose KR, Bartholomew JC, Bradfield CA. 1991. Aromatic hydrocarbon responsiveness-receptor agonists generated from indole-3-carbinol in vitro and in vivo: comparisons with 2,3,7,8-tetrachlorodibenzo-p-dioxin. Proc Natl Acad Sci U S A 88(21):9543-7.

Bovee TF, Hoogenboom LA, Hamers AR, Traag WA, Zuidema T, Aarts JM, Brouwer A, Kuiper HA. 1998. Validation and use of the CALUX-bioassay for the determination of dioxins and PCBs in bovine milk. Food Addit Contam 15(8):863-75.

Chen YH, Riby J, Srivastava P, Bartholomew J, Denison M, Bjeldanes L. 1995. Regulation of CYP1A1 by indolo[3,2-b]carbazole in murine hepatoma cells. J Biol Chem 270(38):22548-55.

Dashwood RH. 1998. Indole-3-carbinol: anticarcinogen or tumor promoter in brassica vegetables? Chem Biol Interact 110(1-2):1-5.

Denison MS, Nagy SR. 2003. Activation of the aryl hydrocarbon receptor by structurally diverse exogenous and endogenous chemicals. Annu Rev Pharmacol Toxicol 43:309-34.

Guzelian P, Quattrochi L, Karch N, Aylward L, Kaley R. 2006. Does dioxin exert toxic effects in humans at or near current background body levels?: An evidencebased conclusion. Hum Exp Toxicol 25(2):99-105.

Hankinson O. 1995. The aryl hydrocarbon receptor complex. Annu Rev Pharmacol Toxicol 35:307-40.

Hoogenboom L, Goeyens L, Carbonnelle S, van Loco J, Beernaert H, Baeyens W, Traag WA, Bovee TF, Jacobs G, Schoeters G. 2006a. The CALUX bioassay: Current status of its application to screening food and feed. Trends in Analytical Chemistry 25(4):410-420.

Hoogenboom R, Bovee T, Traag W, Hoogerbrugge R, Baumann B, Portier L, van de Weg G, de Vries J. 2006b. The use of the DR CALUX bioassay and indicator 
polychlorinated biphenyls for screening of elevated levels of dioxins and dioxinlike polychlorinated biphenyls in eel. Mol Nutr Food Res 50(10):945-57.

Hulshof KFAM, Ocke MC, van Rossum CTM, Buurma-Rethans EJM, Brants HAM, Drijvers JJMM, ter Doest D. 2004. Resultaten van de Voedselconsumptiepeiling 2003 (in Dutch). RIVM. Report nr 350030002/2004. 1-111 p.

Jeuken A, Keser BJG, Khan E, Brouwer A, Koeman J, Denison MS. 2003. Activation of the Ah receptor by extracts of dietary herbal supplements, vegetables, and fruits. Journal of Agricultural and Food Chemistry 51(18):5478-5487.

Kall MA, Vang O, Clausen J. 1996. Effects of dietary broccoli on human in vivo drug metabolizing enzymes: evaluation of caffeine, oestrone and chlorzoxazone metabolism. Carcinogenesis 17(4):793-9.

Kim YS, Milner JA. 2005. Targets for indole-3-carbinol in cancer prevention. J Nutr Biochem 16(2):65-73.

Leibelt DA, Hedstrom OR, Fischer KA, Pereira CB, Williams DE. 2003. Evaluation of chronic dietary exposure to indole-3-carbinol and absorption-enhanced 3,3'diindolylmethane in sprague-dawley rats. Toxicol Sci 74(1):10-21.

Machala M, Vondracek J, Blaha L, Ciganek M, Neca JV. 2001. Aryl hydrocarbon receptor-mediated activity of mutagenic polycyclic aromatic hydrocarbons determined using in vitro reporter gene assay. Mutat Res 497(1-2):49-62.

Murray S, Lake BG, Gray S, Edwards AJ, Springall C, Bowey EA, Williamson G, Boobis AR, Gooderham NJ. 2001. Effect of cruciferous vegetable consumption on heterocyclic aromatic amine metabolism in man. Carcinogenesis 22(9):141320.

Nishiumi S, Yabushita Y, Fukuda I, Mukai R, Yoshida K, Ashida H. 2006. Molokhia (Corchorus olitorius L.) extract suppresses transformation of the aryl hydrocarbon receptor induced by dioxins. Food Chem Toxicol 44(2):250-60.

Pohjanvirta R, Korkalainen M, McGuire J, Simanainen U, Juvonen R, Tuomisto JT, Unkila M, Viluksela M, Bergman J, Poellinger L and others. 2002. Comparison of acute toxicities of indolo[3,2-b]carbazole (ICZ) and 2,3,7,8tetrachlorodibenzo-p-dioxin (TCDD) in TCDD-sensitive rats. Food Chem Toxicol 40(7):1023-32.

Pohl C, Will F, Dietrich H, Schrenk D. 2006. Cytochrome P450 1A1 expression and activity in Caco-2 cells: modulation by apple juice extract and certain apple polyphenols. J Agric Food Chem 54(26):10262-8.

Reed GA, Peterson KS, Smith HJ, Gray JC, Sullivan DK, Mayo MS, Crowell JA, Hurwitz A. 2005. A phase I study of indole-3-carbinol in women: tolerability and effects. Cancer Epidemiol Biomarkers Prev 14(8):1953-60.

Rogan EG. 2006. The natural chemopreventive compound indole-3-carbinol: state of the science. In Vivo 20(2):221-8.

Rost KL, Brosicke H, Brockmoller J, Scheffler M, Helge H, Roots I. 1992. Increase of cytochrome P450IA2 activity by omeprazole: evidence by the $13 \mathrm{C}-[\mathrm{N}-3-$ methyl]-caffeine breath test in poor and extensive metabolizers of Smephenytoin. Clin Pharmacol Ther 52(2):170-80.

Safe S. 2001. Molecular biology of the Ah receptor and its role in carcinogenesis. Toxicology Letters 120(1-3):1-7.

Safe SH. 1998. Development validation and problems with the toxic equivalency factor approach for risk assessment of dioxins and related compounds. J Anim Sci 76(1):134-41. 
Sinha R, Rothman N, Brown ED, Mark SD, Hoover RN, Caporaso NE, Levander OA, Knize MG, Lang NP, Kadlubar FF. 1994. Pan-fried meat containing high levels of heterocyclic aromatic amines but low levels of polycyclic aromatic hydrocarbons induces cytochrome P4501A2 activity in humans. Cancer Res 54(23):6154-9.

Steenland K, Bertazzi P, Baccarelli A, Kogevinas M. 2004. Dioxin revisited: developments since the 1997 IARC classification of dioxin as a human carcinogen. Environ Health Perspect 112(13):1265-8.

Windal I, Denison MS, Birnbaum LS, Van Wouwe N, Baeyens W, Goeyens L. 2005. Chemically activated luciferase gene expression (CALUX) cell bioassay analysis for the estimation of dioxin-like activity: critical parameters of the CALUX procedure that impact assay results. Environ Sci Technol 39(19):735764. 